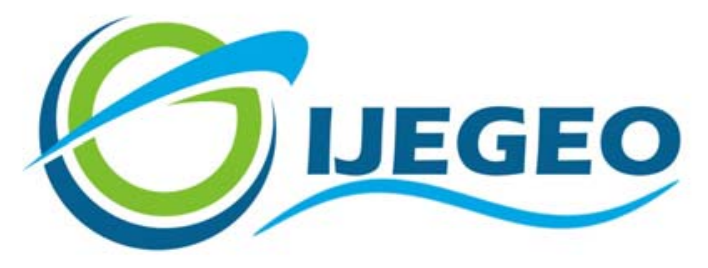

International Journal of Environment and Geoinformatics (IJEGEO) is an international, multidisciplinary, peer reviewed, open access journal.

\title{
Environmental Monitoring of Spatio-Temporal Changes in Northern Istanbul using Remote Sensing and GIS
}

\section{Çiğdem Göksel, Ruusa Magano David and Ahmet Özgür Doğru}

\author{
Editors \\ Prof. Dr. Cem Gazioğlu, Prof. Dr. Dursun Zafer Şeker, Prof. Dr. Ayşegül Tanık, \\ Prof. Dr. Şinasi Kaya, Assist. Prof. Dr. Volkan Demir
}

\section{Scientific Committee (2018)}

Assist. Prof. Dr. Abdullah Aksu, Prof. Dr. Bedri Alpar, Prof. Dr. Gülşen Altuğ, Prof. Dr. Lale Balas, Prof. Dr. Can Balas, Prof. Dr. Levent Bat, Prof. Dr. Bülent Bayram, Prof. Dr. Nuray Çağlar, Prof. Dr. Jadunandan Dash, Prof. Dr. A. Evren Erginal, Assoc. Prof. Dr. Ali Ertürk, Dr. Dieter Fritsch, Dr. Amin Gharehbaghi, Prof. Dr. Melike Gürel, Assoc. Prof. Dr. Tolga Görüm, Dr. Hakan Kaya, Prof. Dr. Fatmagül Kılıç, Assoc. Prof. Dr. Maged Marghany, Prof. Dr. Nebiye Musaoğlu, Prof. Dr. Masafumi Nakagawa, Prof. Dr. Haluk Özener, Prof. Dr. Erol Sarı, Prof. Dr. Elif Sertel, Prof. Dr. Nüket Sivri, Assoc. Prof. Dr. Füsun Balık Şanlı, Prof. Dr. Uğur Şanlı, Assoc. Prof. Dr. Hasan Özdemir, Prof. Dr. Taşkın Kavzoğlu Assoc. Prof. Dr. Oral Yağcı, Dr. Soofia Tahira Elias Özkan, Prof. Dr. Seyfettin Taş, Assist. Prof. Dr. Ömer Suat Taşkın, Dr. İnese Varna, Assoc. Prof. Dr. İ. Noyan Yılmaz, Assist. Prof. Dr. Baki Yokeş, Assit. Prof. Dr. Sibel Zeki 


\title{
Environmental Monitoring of Spatio-Temporal Changes in Northern Istanbul using Remote Sensing and GIS
}

\author{
Çiğdem Göksel ${ }^{1 * *}$, Ruusa Magano David ${ }^{2}$, Ahmet Özgür Doğru ${ }^{1}$ \\ ${ }^{1}$ Faculty of Civil Engineering, Geomatics Engineering Department, Istanbul Technical University, 34469 Maslak, Istanbul, \\ Turkey \\ ${ }^{2}$ Department Istanbul Technical University, Institute of Informatics, Geoinformation Technology Programme, 34469 \\ Maslak, Istanbul, Turkey
}

Corresponding author*

Tel : : +902122853806

E-mail :göksel@itu.edu.tr

Received 09 March 2018

Accepted 31 March 2018

\begin{abstract}
This study aims to evaluate the landscape transformation and the effect of the third Bosphorus Bridge construction works on the natural ecosystem over seven years' time in two districts, Beykoz and Sariyer, located at the northern part of Asian and European Istanbul. The study applied supervised classificationmaximum likelihood algorithm to monitor land cover changes using multi-temporal satellite data of Landsat covering study area for the years of 2009 and 2016. The overall classification accuracies are $92.36 \%$ with Kappa statistic of 0.89 for 2009 and $91.25 \%$ with Kappa statistic of 0.89 for the year 2016. The current study resulted with a rapid land cover change at the study area with approximately $4 \%$ and $\% 1$ decrease in forest and green area, 2\% increase in both agricultural and urban/build up areas. Additionally, the destroyed area increased with approximately $1 \%$ of the study area in the 7 years period.
\end{abstract}

Keywords: Change detection, Land use/cover, Landsat 8 OLI, Supervised classification

\section{Introduction}

Change is an inevitable aspect of the millennial dynamic and ever growing cities. One of the primary issues mentioned and recognized in global environmental approaches is land use/land cover (LU/LC) changes. Nevertheless, these changes can be considered in relation with all aspects at once including the political, socio economic and climatic conditions and factors of the area in research. Many researchers from various disciplines have been exploring the extension and the over-population of the cities along with LU/LC depending on the growth and the urban sprawl.

The transformation of forests and green areas to urban development areas have severely altered not only the quantity but also the quality of the land leading to inevitable problems of soil erosion and deforestation as an unquestionable consequence of LU/LC (Wu, J. 2008). Another noticeable factor that activates LU/LC alterations is the remarkable expansion overseen in urban areas and the direct or indirect population growth. The demand for LU/LC such as built up areas and roads increase according to the increase in the population in a specific area. Therefore, research on how the land is transformed by urbanization and especially land conversion of peri-urban environments has been identified as a pivotal area of future land change research to avoid certain negativities which may affect not only the environment but also its inhabitants.

The actuality, efficiency and certainty of the LU/LC data and information are crucial for a better understanding and evaluation of the consequences of the above-mentioned changes. Through the past decade, remote sensing techniques have been developed, which now have a proven record of accuracy in LU/LC maps and monitoring in a given time period (Zhu, Z. and Woodcock, C. 2014; Ibrahim, M., 2014; Rahman, M. 2016). Moreover, the brief 
and quick developments in remote sensing technologies have led the LU/LC researches to be more effective in terms of tools and data along with being actual and effective in spotting the changes. This is why the Landsat Images are the main sources of data in considering and understanding deforestation and urban growth patterns of the cities (Coppin P. and Bauer, M., 1996; Woodcock, C., 2001).

Spreading the issue to a more anthropogenic perspective, one can say that the transformations and impacts in the natural environment are caused by human activities. A more deepened perspective of anthropology in relation to the ecosystems affected in the urban areas has a profound relationship with LU/LC. Therefore, the above-mentioned aspects of the measured changes are crucially important and valuable because of the spatial characteristics of LU/LC since the human activity cannot be considered apart from the urban developments. Thus, detecting and mapping LU/LC change with an approach based especially on human activities using remote sensing and Geographical Information System (GIS) technologies aid in obtaining a clear understanding of the LU/LC alteration processes due to land use change and their consequences. The present study is focusing on the megacity Istanbul, which is covering both sides of the Bosporus and bridging Europe and Asia continents. Istanbul is a mega city with both natural and historical texture at a strategic geographic location. Historical, cultural and natural beings in Istanbul are subject to the Law of Conservation and have been registered as 'Cultural Heritage' or declared as "Protected Area". In addition, the Bosphorus area is protected with the provisions of a special law. However, even though the municipalities in Turkey are known to have great powers, central government institutions (The Ministry of Environment and Urban Development, The Ministry of Forestry and Water Affairs, The Ministry of Transport) are effective in projecting and constructing major projects. The study examines the land use/cover changes in Istanbul basically arising from such projects.

Two of the main reasons of the land becoming a scarce resource are the agricultural and demographic pressure that requires extraction of information on LU/LC and the possibilities for an optimization while meeting the increasing demand for the human needs. Another point to make is the dynamic nature of LU/LC and the inevitable effect of the anthropogenic factors' altering power on the issue discussed. To be more specific, LU/LC in the Northern parts of Istanbul's metropolitan area is constantly changing over space and time as a result of the rapid growth of the city based on various economic and industrialization efforts (Doğru et all., 2006; Göksel et all., 2006; Şeker et all., 2016). Moreover, the mega construction projects including the third bridge, the sub-sea tunnels and a third airport are all traits of the increasing demand and growth of the city. Even though these aspects are contributing to the social attributes of daily life - and could also be considered as improvements for citizens - their impacts on the nature and the ecosystems are left inevitable and permanent which makes the monitoring of changes profoundly important and needed for effective decisions and to build a balance between the positive sides of the development and the negative effects on the environmental resources caused for an increase in the socioeconomic welfare.

The main objective of this study is to quantify the land use and land cover change trajectories with the multi-temporal Landsat imagery in the northern part of Istanbul Metropolitan area. The study evaluated the landscape transformation at the coastal line and the effect of the third Bosphorus Bridge (Yavuz Sultan Selim Bridge) on the natural ecosystem in two specific districts; Beykoz and Sarıer over a seven years period using GIS and remote sensing technologies.

\section{Materials and Methods}

\section{Study Area, Data and Methodology}

Istanbul is a megacity with over 15 million inhabitants and the dominant center of manufacturing, services, education and culture which produces $40 \%$ of whole Turkey's industrial activities. Istanbul consists of 41 districts all belonging to Istanbul Metropolitan Municipality. Beykoz and Sariyer Districts have been selected as the study area in this research, covering an area of approximately 
55258 ha (Figure 1). The Beykoz and Sariyer Districts are located at the northern section of Asian and European sides of Istanbul respectively, which is the entrance of the Bosphorus (the Strait of Istanbul) from the Black Sea on both sides. The two districts have been affected by a mega $3^{\text {rd }}$ Bridge transportation project, as it is located in a very precarious ecosystem in the Istanbul's northern region consisting of forests, green areas, basins, agricultural land and wetlands which are has biosphere reserve potential (Gazioğlu, et al., 1997; Simav et al., 2015). Among the areas facing ecological disintegration are municapalities where risk levels must be urgently taken into account (Burak et al., 2004; Gazioğlu et al., 2016).

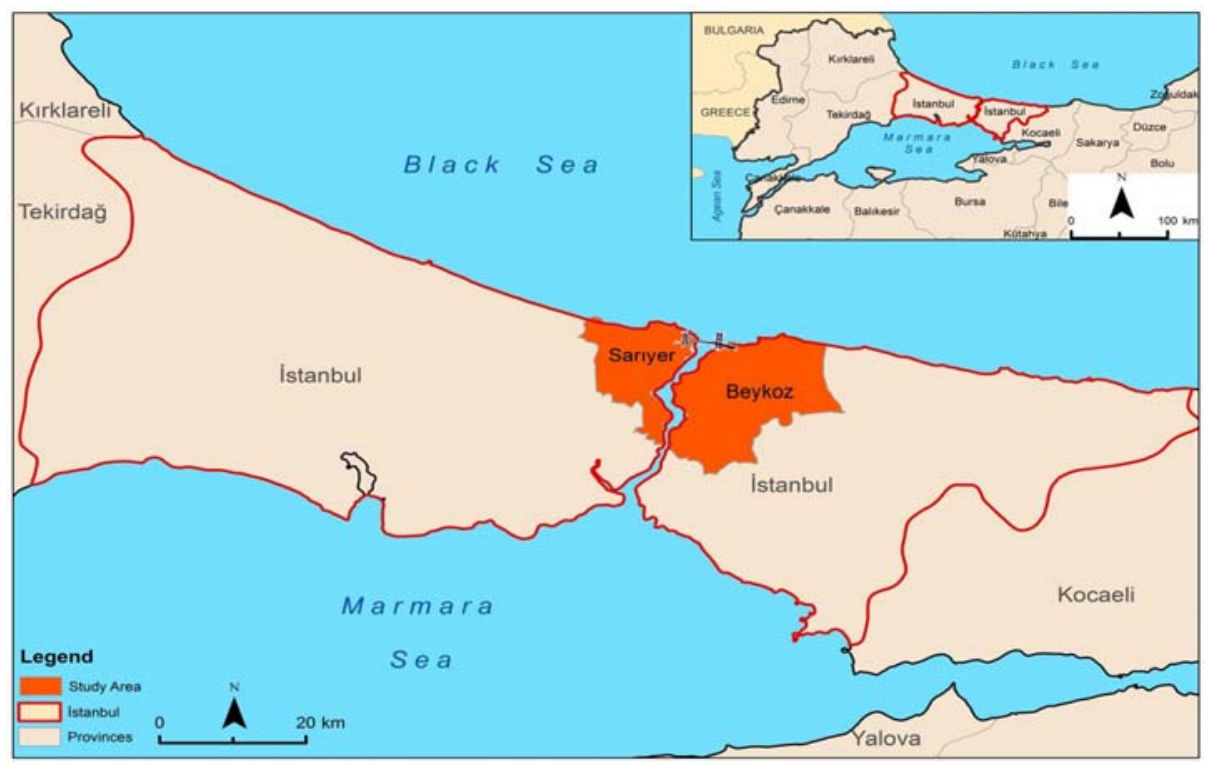

Fig 1. The location of the study area

Two Landsat satellite imageries are used as the main data for LU/LC classifications in the study area for the years of 2009 and 2016. For the year of 2009, Landsat Enhanced Thematic Mapper (ETM+) at a resolution of $30 \mathrm{~m}$ and Landsat Operational Land Imager (OLI) also at a resolution of $30 \mathrm{~m}$ have been utilized. The Landsat data covering study area were obtained from USGS Earth Resources Observation Systems data center (https://www.usgs.gov). In the study, 1:25000 scaled standard topographic maps and 1:5000 scaled ortho-photo maps and google earth imageries have been used as the ancillary data.

Two main steps were involved in this research, which are the classification of the satellite data for LU/LC and the change detection analysis in the LU/LC types. Image registration, orthorectification, classification, and change detection using post-classification comparison were involved in the satellite data analysis.
The reported study has been carried out using Erdas Imagine 2014 and Arcmap 10.x software. The detailed methodology adopted in the study is given in Figure 2.

\subsection{Geometric Correction}

An accurate registration of multispectral remote sensing data is essential for analyzing land use and land cover conditions of a particular geographic location. The geometric correction error between two images is expressed in terms of total root mean square error (RMSE), which represents a measure of deviation of corrected ground control point (GCP) coordinate values from the original reference GCPs used to develop the correction model (Balik Sanli et all. 2008). Change detection analysis is performed on a pixel-by-pixel basis; therefore, any misregistration greater than one pixel will provide an anomalous result of that pixel. To overcome this problem, several authors recommend that the root mean-square error (RMSE) between 
any two dates should not exceed 0.5 pixels (Kardoulas, N. et all 1996; Gong, P. and Xu, B. 2003; Jensen, J. 2004)

In this study, Landsat images were georeferenced to the Universal Transverse Mercator projection system (UTM) using 1:25 000 scaled standard topographic maps. For the rectification process, 22 GCP (Ground Control Points) distributed homogeneously over the images were used. In terms of image rectification, a nearest neighbor resampling algorithm was used. The total RMSE for 2009 and 2016 images were 0.34 and 0.32 pixels, respectively.

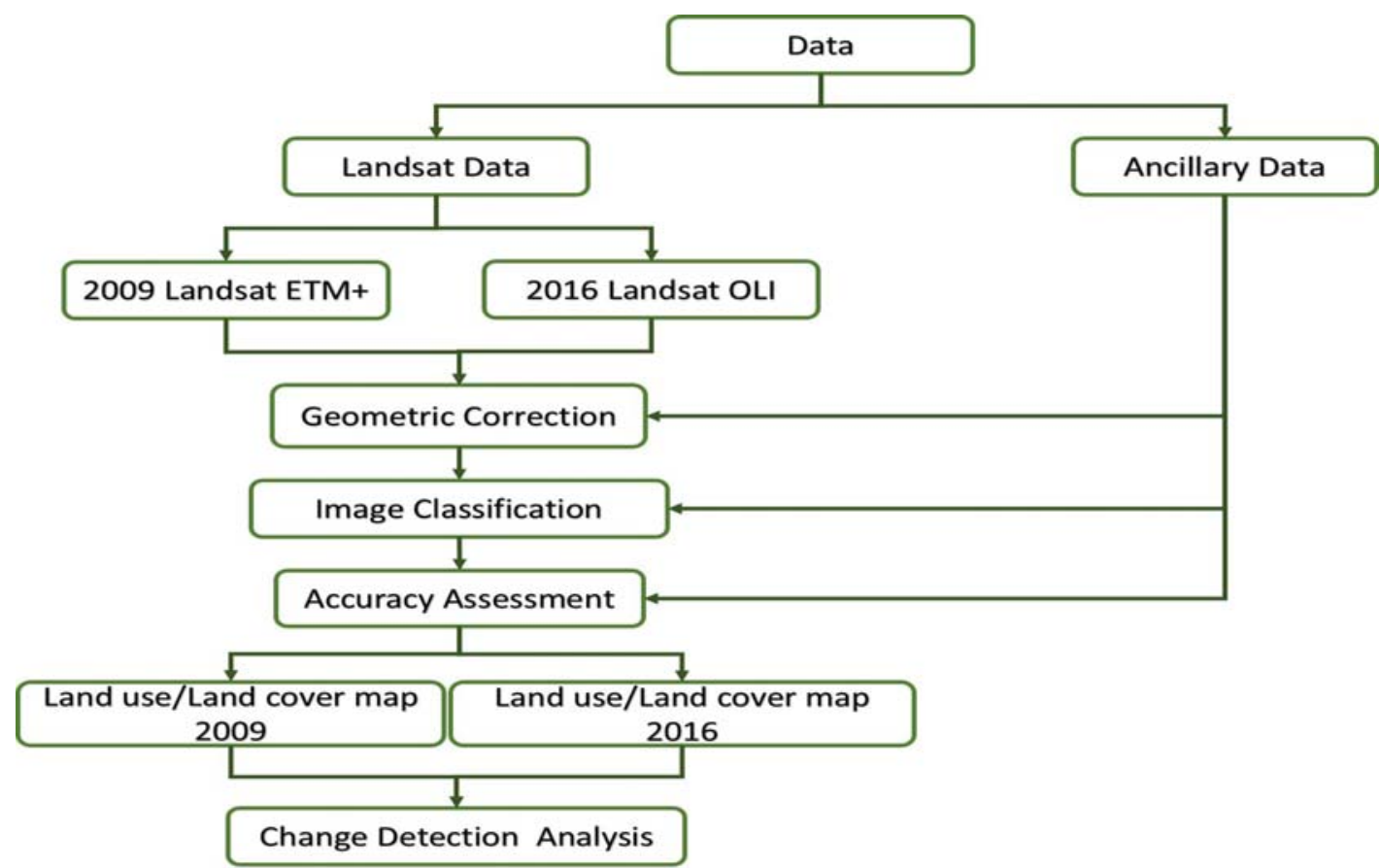

Figure 2. Flowchart of methodology for land use/land cover change

\subsection{Image Classification}

Image classification is usually performed by per pixel labeling of raster data, in many instances the desired result of image classification is a vector-based map of polygons (Lunetta R., et all. 2006). In this study, maximum likelihood classification (MLC) was used to derive LU/LC categories of selected study area. In the supervised classification technique, the maximum likelihood algorithm classifies the image based on the training sets (signatures) provided by the user on the basis of their own knowledge or experiences. In this method, the pixel is assigned to the class to which the probability of the pixel belonging is the highest (Weber, R. and Dunno, G.2005).

\subsection{Accuracy assessment of image} classification

Accuracy Assessment of classified images was carried out to determine the quality of information derived from the data. This is essential as the user of LU/LC maps has the need to know how accurate the maps are in order to use the data more correctly and efficiently (Jensen, J. 2004). Error matrices as cross-tabulations of the mapped class vs. the reference class were used to assess classification accuracy (Smits, P. et all. 1999; Congalton, R. and Green, K. 1999). For the accuracy assessment of land cover maps extracted from satellite images, stratified random method was used to represent different land cover classes of the area. The accuracy assessment was carried out using 300 points that were selected randomly and analyzed based on ground truth data and visual interpretation. 


\subsection{Land use/cover change detection}

Post-classification comparison change detection algorithm was employed by the study to determine changes in land cover in a seven years span. Two classified image pairs were compared using cross-tabulation in order to determine qualitative and quantitative aspects of the changes for the periods from 2009 to 2016. Thus, a change matrix was produced from the two class maps, containing different combinations of "from-to" change information. Landscape transformations that have occurred i.e. the gains and losses in each category between 2009 and 2016 were then compiled and mapped. This information will reveal both the desirable and undesirable changes and classes that are "relatively" stable overtime.

\section{Results}

The overall accuracy, along with the user and producer's accuracies, and the kappa statistic for each class were derived from the error matrix. The achieved overall classification and Kappa coefficient are presented in Table 1.

Table 1. Overall classification accuracies (\%) and kappa statistics

\begin{tabular}{ccc}
\hline Year & $\begin{array}{l}\text { Overall } \\
\text { accuracy }\end{array}$ & Kappa Statistic \\
\hline 2009 & 92.36 & 0.90 \\
\hline 2016 & 91.25 & 0.89 \\
\hline
\end{tabular}

Figure 3 shows the derived LU/LC maps showing the changes in land use and land cover of the study area. These images provide the information about the land use pattern of the Beykoz and Sariyer. In the classification, nine classes were produced for the 2009 image (water, forest, green areas, agricultural land, urban and build-up, roads, sand dunes, bare land and open mining areas). For 2016, ten classes were produced. With the nine classes as in 2009, an additional class of destroyed areas was added. This class is mainly consists of the transportation network of third bridge construction. The 2009 image and the 2016 image were compared in terms of the total area of each LU/LC category. Table 2 present those statistical results of classification.
The results reveals that from 2009 to 2016, the study area experienced land cover changes, the forest area occupied about $47.9 \%$ of the total area in 2009 and has decreased to $44.6 \%$ in 2010. Green areas were also reduced from $9.8 \%$ to $8.7 \%$, respectively. Water bodies and bare land also experienced a reduction in the sevenyear period. On the other hand, urban and build up land have increased from $6.6 \%$ to $8.7 \%$, agricultural land was $6.5 \%$ in 2009 , this number increased to $8.4 \%$ in 2016 . As it can be seen in Table 2, although there is no LU/LC class named as destroyed area in the year of 2009 , this class appeared with approximately $1 \%$ of the whole area in the year of 2016. Open mining area was $1.1 \%$ in 2009 but experienced an increment of $1.7 \%$ in 2016 . Other land cover classes such as roads, sand dunes and open mining areas have also experienced an increase in the course of seven years. Table 2 reveals that both positive and negative changes occurred in the LU/LC pattern of the Beykoz and Sar1yer Districts.

To have a further understanding of land encroachment for different land categories during the seven years period, matrices of land cover changes from 2009 to 2016 (Table 3) was prepared. In the table, unchanged pixels are located along the major diagonal of the matrix. When the direction of the change has been evaluated, out of 26504.9 ha that was forest in 2009, 22368.7 ha was still forest in 2016 but 2030.4 ha was converted to green areas, 820 ha was converted to agricultural land, 512.8 ha was converted to bare land and 227.9 ha became destroyed areas in 2016. Additionally, at the same time the increase of agriculture, from 2009 to 2016, was mainly from forest area and green areas. The agricultural land gained 1308.8 ha from green areas and 820 ha was obtained from forest areas as mentioned before. The class that destroyed area mainly replaced in 2016 was forest, followed by green areas and agricultural land. The destroyed area replaced around 227.9 ha of forest area and it took equal portion of land from the green areas and the agricultural land, 45.4 ha from each class. The results show that the most important land cover types in the northern areas were affected by the construction of the third bridge and so as a large portion of the forests in comparison to other classes. 


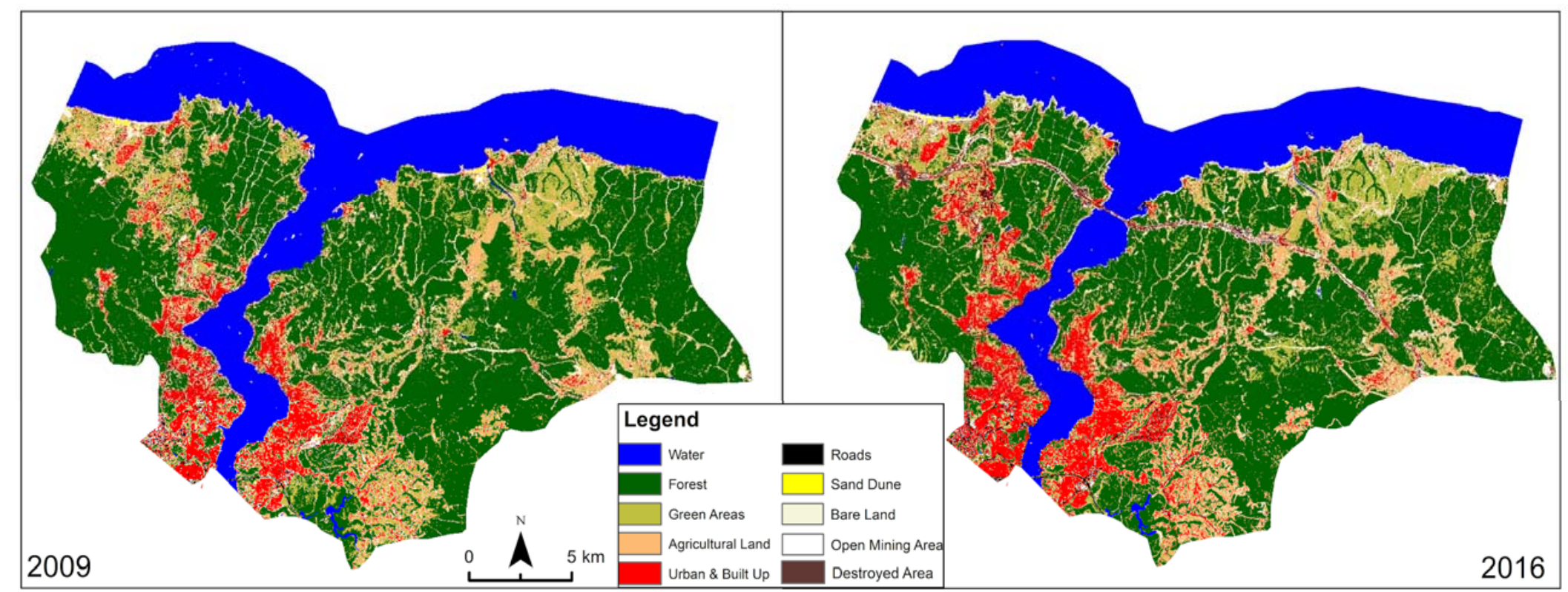

Figure 3. LU/LC in 2009 and 2016 
Göksel et al., / IJEGEO 5(1): 5(1): 94-103 (2018)

\begin{tabular}{|c|c|c|c|c|c|c|}
\hline Land Cover Type & $\begin{array}{l}2009 \\
\text { (TM) } \\
\text { area } \\
\text { (ha) }\end{array}$ & $\begin{array}{l}\text { Percentage } \\
\text { of the area }\end{array}$ & $\begin{array}{l}2016 \\
\text { (OLI) } \\
\text { area (ha) }\end{array}$ & $\begin{array}{l}\text { Percentage } \\
\text { of the area }\end{array}$ & $\begin{array}{l}\text { Sum of } \\
\text { the area } \\
\text { (ha) }\end{array}$ & $\begin{array}{l}\text { Change } \\
\text { Between } \\
\text { Both } \\
\text { Years }\end{array}$ \\
\hline Water & 11733.8 & 21.2 & 11513.1 & 20.8 & -220.7 & -0.4 \\
\hline Forest & 26504.9 & 47.9 & 24654.6 & 44.6 & -1850.3 & -3.3 \\
\hline Green areas & 5463.3 & 9.8 & 4838.3 & 8.7 & -624.9 & -1.1 \\
\hline Agricultural land & 3625.2 & 6.5 & 4653.5 & 8.4 & 1028.3 & 1.9 \\
\hline Urban and build up & 3675.6 & 6.6 & 4851.1 & 8.7 & 1175.5 & 2.1 \\
\hline Roads & 723.9 & 1.3 & 825.5 & 1.5 & 101.6 & 0.2 \\
\hline Sand dune & 107.5 & 0.2 & 122.4 & 0.2 & 14.9 & 0.03 \\
\hline Bare land & 2835.6 & 5.1 & 2340 & 4.2 & -495.6 & -0.9 \\
\hline Open mining area & 589 & 1.1 & 984.3 & 1.7 & 395.3 & 0.7 \\
\hline Destroyed Area & 0 & 0.0 & 476 & 0.8 & 476 & 0.9 \\
\hline TOTAL & 55258.8 & 100 & 55258.8 & 100 & & \\
\hline
\end{tabular}

Table 3. Matrices of land use land cover (ha) from 2009 to 2016

\begin{tabular}{|c|c|c|c|c|c|c|c|c|c|c|c|}
\hline LC Type & $\mathrm{W}$ & $\mathrm{F}$ & $\mathrm{GA}$ & $\mathrm{AL}$ & $\mathrm{U} \& \mathrm{~B}$ & $\mathrm{R}$ & $\mathrm{SD}$ & $\mathrm{BL}$ & $\mathrm{OA}$ & $\mathrm{DA}$ & $\begin{array}{l}\mathrm{TOT} \\
2016\end{array}$ \\
\hline Water-W & 11474.4 & 18.1 & 0.30 & 4.1 & 0.9 & 2 & 1 & 0.4 & 11.9 & 0 & 11513.1 \\
\hline Forest-F & 13.8 & 22368.7 & 1478.1 & 200.4 & 13.3 & 36.2 & 0 & 541.6 & 2.5 & 0 & 24654.6 \\
\hline Green areas_GA & 1.00 & 2030.4 & 1531.4 & 661.1 & 49 & 68.7 & 5.8 & 458.9 & 32 & 0 & 4838.33 \\
\hline Agricultural Land-AL & 2 & 820 & 1308.8 & 1271.1 & 293.9 & 115.4 & 14.7 & 768.8 & 58.8 & 0 & 4653.5 \\
\hline $\begin{array}{c}\text { Urban \&Build up- } \\
\text { U\&B }\end{array}$ & 11.7 & 203 & 301.8 & 640.1 & 2875.5 & 225.5 & 15.3 & 441.6 & 136.6 & 0 & 4851.1 \\
\hline Roads-R & 71.2 & 77.7 & 79.3 & 110.7 & 179.4 & 145.7 & 5 & 72.2 & 84.3 & 0 & 825.5 \\
\hline Sand Dunes-SD & 43.2 & 10.1 & 3 & 10 & 11.1 & 5.8 & 17.6 & 2.6 & 19 & 0 & 12.4 \\
\hline $\begin{array}{c}\text { Open Mining Areas- } \\
\text { OA }\end{array}$ & 10.5 & 512.8 & 624.5 & 525.4 & 117.2 & 53.2 & 10.8 & 421.7 & 63.9 & 0 & 2340 \\
\hline Bare land- BL & 98.6 & 236.2 & 90.7 & 156.9 & 92.5 & 54.9 & 24.2 & 95 & 135.3 & 0 & 984.3 \\
\hline Destroyed Areas- DA & 7.4 & 227.9 & 45.4 & 45.4 & 42.8 & 16.5 & 13.1 & 32.8 & 44.7 & 0 & 476 \\
\hline TOTAL 2009 & 11733.8 & 26504.9 & 5463.3 & 3625.2 & 3675.6 & 723.9 & 107.5 & 2835.6 & 589 & 0 & 55258.8 \\
\hline
\end{tabular}


Urban and build up increased from 3675.6 ha in 2009 to 4851.1 ha in 2016 . It replaced 640.1 ha of agricultural land and 301.8 ha of green areas. Around 99 ha of water was replaced by the open and mining areas, whereas the area of other land cover classes replaced by water was relatively small.

A While the above change statistics shed a little light on the question of where land use changes are occurring, constructing a change detection map Figure 4 can show the exact changes in the land cover types and can be much more appreciated.

The third bridge construction along the Bosphorus was referred to as (destroyed areas class) in the study and the most important conversion in the Beykoz and Saryer areas. It can also be seen in the Figure 4 that the major area of forest was converted to the transportation ring along the Bosphorus on the European and Asian side of Istanbul city. The dark brown colour in Figure 5 along the Bosphorus trait represent the forest area turned into the "destroyed area class" which represent the ring of the Yavuz Sultan Selim Bridge.

This study elucidates the significance of incorporating Remote Sensing and GIS for change detection study of land cover/land use of an area as it offers essential information about the spatial distribution as well as nature of landscape transformation.

\section{Discussion and Conclusion}

The land cover changes between different times Interval have been visualized and analyzed by

using remote sensing technology. The results clearly reveal that LU/LC changes were significant during the period between 2009 and 2016. Also, Landsat classifications can be utilized to produce accurate land cover change maps and statistics that can be used to monitor the changes occurred and its impacts on the environment have been demonstrated. It can be seen that there is a significant decrease in forest, green areas density in the northern part

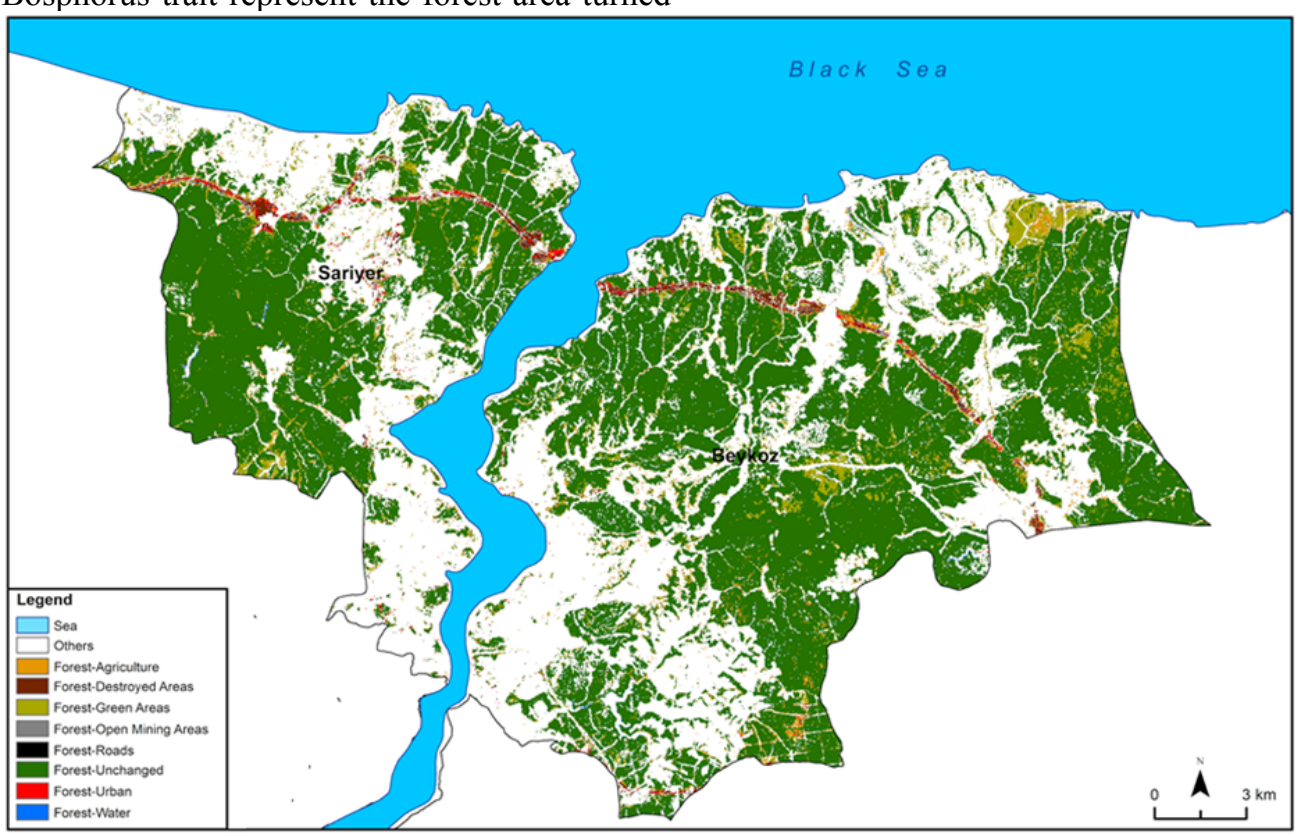

Figure 4. Forest areas in Beykoz and Sarıyer Districts

of Istanbul where main changes appeared from 2009 to 2016. It was observed that the developmental activities and the construction of new roads and bridges as a result of urbanization were the major reasons for the dramatic LU/LC changes that took place in the study area.

It is obvious that Bosphorus bridges linking Asia and Europe serve a high portion of urban 
traffic with a high capacity due to increasing population and intercontinental traffic. In this sense, the Third Bosphorus Bridge will contribute to reducing this density with 8 lane roads and 2 high-speed railway lines. Beykoz and Saryer, the study areas, are the most populated areas of forest and shrubbery in Istanbul. Based on the previous experiences on first and second bridge construction projects in Istanbul, it is known that such projects promoted the urban growth around the project sites and large amount of agricultural and forest lands were damaged. The study introduced that the change arisen from the construction of the $3^{\text {rd }}$ Bridge and its service roads is not large enough, for both districts, rent-focused unplanned urbanization episodes are considered as a potential danger. Decisions and sanctions for protection to be taken by local governments, as well as government agencies' decisionmaking mechanisms, will contribute to further deterioration and protection of the natural areas and land of the region.

These results have highlighted the increasing rate of modification of forest ecosystem by anthropogenic activities and the need to apprehend the situation to ensure sustainable environmental management. The quantification of LU/LC changes of Beykoz and Sariyer area is very useful for environmental management groups, policy makers and for public to better understand the impacts the developmental activities have on the green areas and forested land in the area and the surrounding. The general LU/LC changes trends determined in this study, and the variable outputs associated with these LU/LC, can be used as input by decision makers during the planning phase of the similar mega projects.

\section{References}

Balık, Şanlı, F.; Bektas, Balcık, F. and Göksel, Ç. (2008). Defining temporal spatial patterns of mega city Istanbul to see the impacts of increasing population. Environmental Monitoring and Assessment, 146: $267-275$

Burak, S., Doğan, E. and Gazioğlu, C. (2004). Impact of urbanization and tourism on coastal environment. Ocean and Coastal Management 47(9-10): 515-527.
Congalton, RG. and Green, K. (1999) Assessing the accuracy of remotely sensed data: principles and applications. Lewis Publishers, Boca Raton, Fla, 43-64.

Coppin, PR. and Bauer, ME. (1996). Digital change detection in forest ecosystems with remote sensing imagery. Remote Sensing Reviews, 13(3-4), 207-234.

Doğru, OA.; Bektas Balcık, F.; Göksel, Ç. and Uluğtekin, N. (2006). Monitoring coastal dunes by using remote sensing and GIS integration in northwest Turkey: A case study of Kilyos dunes. Fresenius Environmental Bulletin PSP,Volume 15 No 9b, pp 1216-1220.

Gazioğlu C, Yücel Y Z, Burak S., Okuş, E. and Alpar, B. (1997). Coastline change and inadequate management between Kilyos and Karaburun shoreline. Turkish Journal of Marine Sciences, 3(2): 111-122.

Gazioğlu, C., Akkaya, M.A., Baltaoğlu, S. and Burrak, S.Z. (2016). ICZM and the Sea of Marmara: The İstanbul Case. The Sea of Marmara: Marine Biodiversity, Fisheries, Conservations and Governance (Editors: Özsoy, E., Çağatay, M.N., Balkıs, N., Balkıs Çağlar, N., Öztürk, B.): 935-957.

Göksel, C.; Musaoğlu, N.; Gürel, M.; Uluğtekin, N.; Tanık, A. and Şeker, DZ. (2006). Determination of land-use change in an urbanized district of Istanbul via remote sensing analysis. Fresenius Environmental Bulletin (FEB), 15(8A): 798-805.

Gong, P. and Xu, B. (2003). Remote sensing of forests over time: changes types, methods, and opportunities. In Remote Sensing of Forest Environments: Concepts and Case Studies, Woulder M, Franklin SE (ed), 301333, Amsterdam: Kluwer Press.

İbrahim, Mahmoud, M.; Duker, A.; Conrad, C.; Thiel, M.; Shaba and Ahmad, H. (2016). Analysis of settlement expansion and urban growth modelling using geoinformation for assessing potential impacts of urbanization on climate in Abuja City, Nigeria. Remote Sensing, 8(3): 220 .

Jensen, JR.. (2004). Introductory Digital Image Processing: A remote sensing perspective, (3rd ed.), Upper Saddle River, NJ: Prentice Hall.

Kardoulas, NG.; Bird, AC. and Lawan, AI. (1996). Geometric correction of spot and Landsat imagery: A comparison of map- 
and GPS-derived control points. Photogrammetric Engineering and Remote Sensing, 62: 1173-1177.

Lunetta, RS.; Knight, JF.; Ediriwickrema, J.; Lyon, JG. and Worthy, LD. (2006). Landcover change detection using multitemporal MODIS NDVI data. Remote Sensing of Environment, , 105(2): 142-154.

Rahman, MT. (2016). Detection of Land Use/Land Cover Changes and Urban Sprawl In Al-Khobar, Saudi Arabia: An Analysis of Multi-Temporal Remote Sensing Data. ISPRS International Journal of GeoInformation. 5(2): 15.

Şeker D.Z., Tanık, A., Citil, E., Ozturk, I., Ovez, S. and Baycan, T. (2016). Importance and Vulnerability Analyses for Functional Zoning in a Coastal District of Turkey. International Journal of Environment and Geoinformatics. 2016. Vol 3 (3): 76-91.

Simav, Ö., Şeker, D.Z., Tanık, A., Gazioğlu, C. (2015). Determining the endangered fields of Turkish coasts with coastal vulnerability index. Journal of Map, 153: 1-8.

Smits, PC.; Dellepaine, SG. and Schowengerdt, RA. (1999). Quality assessment of image classification algorithms for land cover mapping: A review and a proposal for a cost based approach. International Journal of Remote Sensing, 20: 1461-1486.

Weber, R.M and Dunno, G.A. (2001). Riparian vegetation mapping and image processing techniques, Hopi Indian Reservation. Photogrammetry Engineering Remote Sensing. 67(2), 179-186.

Woodcock, CE.; Macomber, SA.; Pax-Lenney, M. and Cohen, WB. (2001). Large area monitoring of temperate forest change using Landsat data: generalization across sensors, time and space.Remote Sensing of Environment. 78(1-2): 194-203.

Wu, J. (2008). Land Use Changes: Economic, social, and environmental impacts. Choices., 23(4):6-10.

Zhu, Z. and Woodcock, CE. (2014). Continuous change detection and classification of land cover using all available Landsat data. Remote Sensing of Environment, 144, pp. 152-171. 